\title{
Photochemotherapeutic strategies against Acanthamoeba keratitis
}

\author{
Ruqaiyyah Siddiqui and Naveed Ahmed Khan ${ }^{*}$
}

\begin{abstract}
Here, we determined the potential of photochemotherapy, namely the application of photodynamic compounds followed by exposure to a suitable source of UV-visible radiation against corneal pathogen, Acanthamoeba. Organometallic macromolecule, tin porphyrin [Sn(IV)porphyrin] was synthesized and purity confirmed using nuclear magnetic resonance spectroscopy. The Sn(IV)porphyrin was tested against a keratitis isolate of Acanthamoeba castellanii belonging to the T4 genotype using growth and viability assays. The effects of Sn(IV)porphyrin on A. castellanii binding to and cytopathogenicity of human corneal epithelial cells in vitro were tested. The metalloporphyrin showed potent amoebistatic effects. The tin porphyrin inhibited amoebae binding to and cytopathogenicity of corneal epithelial cells. By using derivatives of photodynamic compounds [Sn(IV)porphyrinantibody conjugates] for selective targeting of the parasite together with appropriate selection of light source will determine the potential of photochemotherapy against Acanthamoeba keratitis.
\end{abstract}

Keywords: Acanthamoeba, Keratitis, Tin porphyrin, Treatment, Drug resistance, NMR

\section{Introduction}

Due to increasing resistance of infectious microorganisms to antimicrobial agents, it is becoming obvious to find alternative strategies for successful treatment of these devastating infections. Among others, Acanthamoeba keratitis is a serious human disease with sightthreatening consequences (Khan, 2009). Current treatment is problematic and involves hourly topical application of a cocktail of drugs including chlorhexidine, polyhexamethylene biguanide, propamidine isethionate, neomycin, and even then recurrence can occur (Ficker et al., 1990; Perez-Santonja et al., 2003). This is of particular concern in the absence of available alternative chemotherapeutic agents.

Photochemotherapy, namely the application of photodynamic compounds followed by exposure to a suitable source of UV-visible radiation, holds promise in future antimicrobial therapy (Hamblin and Hasan, 2004; Huang et al., 2010), particularly in eye infections due to ease of visible light usage. Here, we determined the potential of photodynamic compound, Sn(IV)porphyrin against a eukaryotic corneal pathogen, Acanthamoeba. Sn(IV)

\footnotetext{
* Correspondence: Naveed5438@gmail.com

Department of Biological and Biomedical Sciences, Aga Khan University, Karachi, Pakistan
}

porphyrin is a synthetic metalloporphyrin that is a suitable tin porphyrin for catalytic and photocatalytic application because of the presence of a single metal oxidation state (Sardana and Kappas, 1987). Additionally, many derivatives can be formed with a variety of anions, which is important in the synthesis of an efficient photosensitizer. The formation of these derivatives is possible owing to the $\mathrm{Sn}(\mathrm{IV})$ centre, which is usually six-coordinate with two trans-diaxial ligands.

\section{Methods}

\section{Synthesis of $\mathrm{Sn}(\mathrm{IV})$ porphyrin}

$\mathrm{Sn}(\mathrm{IV})$ porphyrin was synthesized as follows: $250 \mathrm{mg}$ of $5,10,15,20$-meso tetraphenyl porphyrine (TPP) and $200 \mathrm{mg}$ stannous chloride $\left(\mathrm{SnCl}_{2} \cdot 2 \mathrm{H}_{2} \mathrm{O}\right)$ were stirred and refluxed in $25 \mathrm{~mL}$ of pyridine in condensor at $115^{\circ} \mathrm{C}$ for $24 \mathrm{~h}$. Approximately, $150 \mathrm{~mL} \mathrm{H}_{2} \mathrm{O}$ was added and the solution was allowed to cool at room temperature. The crystals of $\mathrm{Sn}(\mathrm{IV})$ porphyrin were collected by vacuum filtration, washed with water and dried by vacuum suction yielding $250 \mathrm{mg}$ of product, which showed maximum solubility in DMSO. The stock solution of Sn(IV) porphyrin was maintained in $10 \mathrm{mM}$ concentration and stored in $-4^{\circ} \mathrm{C}$.

\section{穴 Springer}




\section{Growth and viability assays}

The effects of Sn(IV)porphyrin on Acanthamoeba viability and growth were determined. A clinical isolate of $A$. castellanii from a keratitis patient (ATCC 50492) was grown in PYG and incubated with Sn(IV)porphyrin (10, $50,100 \mu \mathrm{M})$ in 24-well plates $\left(2.5 \times 10^{5}\right.$ amoebae $/ \mathrm{mL} /$ well $)$ for $24 \mathrm{~h}$ under visible light. Amoebicidal and amoebistatic effects were determined using haemocytometer counting (Siddiqui et al., 2012) and Trypan blue exclusion testing (Thorson et al., 1995). For controls, amoebae were incubated with solvent alone (i.e., DMSO). Normal growth rates were determined using growth medium alone and considered as $100 \%$. The results were presented as relative percent of $A$. castellanii incubated in PYG. Experiments were performed in duplicate and repeated at least three times.

\section{Adhesion assays}

Adhesion assays were performed to determine the effects of $\mathrm{Sn}(\mathrm{IV})$ porphyrin on $A$. castellanii binding to human corneal epithelial cells (HCEC). HCEC were grown to confluency in 24-well plates in RPMI-1640 containing $10 \%$ foetal calf serum and $2 \mathrm{mM}$ glutamine (Sissons et al., 2005; Araki-Sasaki et al., 2000). A. castellanii $\left(10^{6}\right.$ amoebae/well) were pre-incubated with various concentrations of $\mathrm{Sn}(\mathrm{IV})$ porphyrin or solvent alone for $45 \mathrm{~min}$ under visible light and then added to cell monolayers for $1 \mathrm{~h}$ and percentage binding determined as follows: 100 - [no. of unbound amoebae/total number of amoebae $\mathrm{x} 100]=\%$ bound amoebae.

\section{Cytopathogenicity assays}

Cytopathogenicity assays were performed to determine effects of $\mathrm{Sn}(\mathrm{IV})$ porphyrin on $A$. castellanii-mediated HCEC death. Amoebae were pre-incubated with Sn(IV) porphyrin or solvent alone as per adhesion assays. Amoebae were collected by centrifugation and resuspended in RPMI 1640 without Sn(IV)porphyrin and added to cell monolayers. Plates were incubated at $37^{\circ} \mathrm{C}$ in a $5 \% \mathrm{CO}_{2}$ incubator for $24 \mathrm{~h}$. Cytopathogenicity was determined by measuring lactate dehydrogenase release as follows: (sample value - control value/total LDH release - control value $\mathrm{x} 100=\%$ cytopathogenicity) (Sissons et al., 2005). Control values were obtained from HCEC incubated in RPMI alone. Total LDH release was determined from HCEC treated with 5\% Triton X-100 for $30 \mathrm{~min}$ at $37^{\circ} \mathrm{C}$.

\section{Results}

NMR spectroscopy confirmed the purity of Sn(IV) porphyrin

To confirm purity of Sn(IV)porphyrin, octahedral Sn(IV) complex, $\mathrm{TPPSnCl}_{2}$ was dissolved in C6D6 solvent and studied for chemical shifts and couplings constants between different position of hydrogen atoms. The calculated meso proton chemical shift for TPP complex was $9.02 \mathrm{ppm}$ and average coupling constant $J(\mathrm{SnH})$ was found to be $14.9 \mathrm{~Hz}$. The results calculated from NMR spectrum were tallied with experimental study of where their chemical shift was 9.18 (our experiment revealed 9.02) and average coupling constant was $15.2 \mathrm{~Hz}$ (our experiment revealed $14.7 \mathrm{~Hz}$ ), indicating similarities in the structure of the molecule and the number of neighboring NMR active nuclei within the molecule. Overall, NMR spectrum revealed chemical shift $(\sigma)$ at meso proton signal ( $\beta$ pyrrole) to be $9.02 \mathrm{ppm}$. Average of ${ }^{119} \mathrm{Sn}-{ }^{1} \mathrm{H}$ and ${ }^{117} \mathrm{Sn}-{ }^{1} \mathrm{H}$ coupling constants, i.e., $J(\mathrm{SnH})$ to meso proton $(\beta$ pyrrole) was $14.7 \mathrm{~Hz}$.

\section{Sn(IV)porphyrin inhibited $A$. castellanii growth but no effect on its viability}

At micromolar concentrations, Sn(IV)porphyrin exhibited significant amoebistatic effects compared with amoebae incubated with solvent alone $(P<0.05$, as standard level of significance, when $\mathrm{Sn}(\mathrm{IV})$ porphyrin-treated samples were compared with solvent-treated samples using $T$-test, paired, one-tail distribution) (Table 1). Both $10 \mu \mathrm{M}$ and $50 \mu \mathrm{M}$ concentrations of $\mathrm{Sn}(\mathrm{IV})$ porphyrin inhibited amoebae growth by $51 \% \pm 6.3$ and $73 \% \pm 4.4$ respectively, while solvent alone inhibited $A$ castellanii growth by $12 \% \pm 2.1$ (Table 1). In contrast, $\mathrm{Sn}(\mathrm{IV})$ porphyrin had no effect on the viability of $A$. castellanii (Table 1 ).

\section{Sn(IV)porphyrin inhibited $A$ castellanii adhesion to and cytopathogenicity of human corneal epithelial cells}

The results revealed that $\mathrm{Sn}(\mathrm{IV})$ porphyrin significantly reduced amoebae binding to HCEC monolayers, compared with amoebae incubated with solvent $(P<0.05$ as

Table 1 Effect of Sn(IV)porphyrin on biological properties of Acanthamoeba castellanii

\begin{tabular}{lcccc}
\hline & $\begin{array}{c}\text { \% Growth } \\
\text { inhibition }\end{array}$ & $\begin{array}{c}\text { \% Viability } \\
\text { inhibition }\end{array}$ & $\begin{array}{c}\text { \% Adhesion } \\
\text { inhibition }\end{array}$ & $\begin{array}{c}\text { \% Cytopathogenicity } \\
\text { inhibition }\end{array}$ \\
\hline Acanthamoeba + solvent & $12 \% \pm 2.1$ & $2.1 \% \pm 1.1$ & $6.8 \% \pm 0.4$ & $11.7 \% \pm 0.8$ \\
Acanthamoeba + Sn(IV)porphyrin $(10 \mu \mathrm{M})$ & $51 \% \pm 6.3$ & $4.5 \% \pm 0.3$ & $12.7 \% \pm 2.3$ & $15.4 \% \pm 2.2$ \\
Acanthamoeba + Sn(IV)porphyrin $(50 \mu \mathrm{M})$ & $73 \% \pm 4.4$ & $7.3 \% \pm 2.2$ & $44 \% \pm 4.1$ & $58.8 \% \pm 6.2$ \\
Acanthamoeba + Sn(IV)porphyrin & $98.2 \% \pm 5.3$ & $12.7 \% \pm 1.3$ & $67 \% \pm 3.2$ & $72.3 \% \pm 5.2$ \\
$(100 \mu \mathrm{M})$ & & & &
\end{tabular}

Data are presented as the mean \pm standard error of three independent experiments performed in duplicate. 
standard level of significance using $T$-test, paired, onetail distribution) (Table 1). At $50 \mu \mathrm{M}$ and $100 \mu \mathrm{M}$ concentrations, $\mathrm{Sn}(\mathrm{IV})$ porphyrin inhibited amoebae binding to HCEC monolayers by $44 \% \pm 4.1$ and $67 \% \pm 3.2$ respectively. A. castellanii incubated with solvent had no effect on adhesion of amoebae to HCEC. Cytopathogenicity assays were performed to determine the effect of $\mathrm{Sn}$ (IV)porphyrin on A castellanii-mediated HCEC death. A. castellanii alone produced $85 \% \pm 3.8$ HCEC death within $24 \mathrm{~h}$. With solvent, A. castellanii-mediated HCEC death was inhibited by $11.7 \% \pm 0.8$. In the presence of $50 \mu \mathrm{M} \mathrm{Sn}(\mathrm{IV})$ porphyrin, A. castellanii-mediated HCEC cytopathogenicity was significantly inhibited $58.8 \% \pm 6.2(P<0.05$ when Sn(IV)porphyrin-treated samples were compared with solvent-treated samples using $T$-test, paired, one tail distribution), which was further reduced to $72.3 \% \pm 5.2$ at $100 \mu \mathrm{M}$ of $\mathrm{Sn}(\mathrm{IV})$ porphyrin respectively.

\section{Discussion}

For the first time, these studies indicate that organometallic macromolecule, tin porphyrin [Sn(IV)porphyrin] exhibit potent amoebistatic effects suggesting that photochemotherapy holds promise in future antimicrobial therapy, particularly in eye infections due to ease of visible light usage. The use of visible light in our findings is particularly significant as the present mode of eye inspection is visible light. The basis of this technology is that visible light (or light of appropriate wavelength) activates photosensitising compound, resulting in production of singlet oxygen and other reactive oxygen species (ROS) to induce cell death in the target pathogen/tissue. If photosensitising compounds can be specifically delivered to the pathogen, there will be several advantages over the present treatment of Acanthamoeba keratitis, which is laborious and involves hourly topical application of mixture of drugs including chlorhexidine, polyhexamethylene biguanide (PHMB), neomycin and propamidine isethionate that can last up to a year with associated side effects and even then recurrence can occur (Khan, 2009). In the present study, the synthetic $\mathrm{Sn}(\mathrm{IV})$ porphyrin macromolecule incorporated a closed shell $\mathrm{Sn}(\mathrm{IV})$ into the porphyrin molecule affecting the ground state optical spectrum and fluorescence spectrum. This photophysical or photosensitizing property of the diamagnetic complex i.e., $\mathrm{Sn}(\mathrm{IV})$ porphyrin shows an increased triplet state lifetime important for photoactive damage (Land et al., 1988).

Targeted treatment of eukaryotic pathogen remains a major problem in our efforts to counter infectious diseases. As opposed to bacterial pathogens with unique targets, the molecular and functional similarities in eukaryotic pathogens to human cells make it particularly challenging to find novel targets for therapeutic interventions. The synthesis of derivatives of these photodynamic compounds in order to improve their selective attachment to the parasite is a complete new approach to this infection. To this end, studies have shown the presence of an adhesin, mannose-binding protein (MBP) on the surface membranes of Acanthamoeba that is critical in its pathogenesis (Alsam et al., 2003; Garate et al., 2004). For robust and targeted killing, future studies will synthesize photosensitizer-alpha-D-mannose conjugates of varying charges as well as photosensitizer-MBP antibody conjugates. This together with appropriate selection of light source (lasers) to emit monochromatic light in the visible spectrum in a given direction targeting and fully activating the photosensitizer compound will determine the potential of photochemotherapy to counter this devastating infection. In addition, these studies will provide a model and stimulate ongoing research in targeting other pathogens, which cause serious eye infections.

\section{Ethical approval}

Not required.

\section{Competing interest}

The authors declare (1) no conflicts of interests for the submitted work; (2) no financial relationships with commercial entities that might have an interest in the submitted work; (3) no spouses, partners, or children with relationships with commercial entities that might have an interest in the submitted work; and (4) no non-financial interests that may be relevant to the submitted work

\section{Funding}

This work was supported by Life Science grants from Birkbeck, University of London, the Higher Education Commission, Pakistan and the Aga Khan University.

\section{Acknowledgements}

The authors are grateful to Dr. Peter Heard and Siuli Bose (Birkbeck, University of London, England, UK) for technical assistance.

Received: 30 April 2012 Accepted: 30 August 2012

Published: 5 September 2012

\section{References}

Alsam S, Kim KS, Stins M, Rivas AO, Sissons J, Khan NA (2003) Acanthamoeba interactions with human brain microvascular endothelial cells. Microb Pathogen 35:235-241

Araki-Sasaki K, Aizawa S, Hiramoto M, Nakamura M, Iwase O, Nakata K, Sasaki Y, Mano T, Handa H, Tano Y (2000) Substance P-induced cadherin expression and its signal transduction in a cloned human corneal epithelial cell line. J Cell Physiol 182:189-195

Ficker L, Seal D, Warhurst D, Wright P (1990) Acanthamoeba keratitis-resistance to medical therapy. Eye 4:835-838

Garate M, Cao Z, Bateman E, Panjwani N (2004) Cloning and characterization of a novel mannose-binding protein of Acanthamoeba. J Biol Chem 279:2984929856

Hamblin MR, Hasan T (2004) Photodynamic therapy: a new antimicrobial approach to infectious disease? Photochem Photobiol Sci 3:436-450

Huang L, Dai T, Hamblin MR (2010) Antimicrobial photodynamic inactivation and photodynamic therapy for infections. Methods Mol Biol 635:155-173

Khan NA (2009) Acanthamoeba. Biology and Pathogenesis. Caister Academic Press, Norfolk, UK, p 290. ISBN 978-1-904455-43-1

Land EJ, McDonagh AF, McGarvey DJ, Truscott TG (1988) Photophysical studies of tin(IV)-protoporphyrin: potential phototoxicity of a chemotherapeutic agent proposed for the prevention of neonatal jaundice. Proc Natl Acad Sci USA 85:5249-5253 
Perez-Santonja JJ, Kilvington S, Hughes R, Tufail A, Metheson M, Dart JKG (2003) Persistently culture positive Acanthamoeba keratitis; in vivo resistance and in vitro sensitivity. Ophthalmol 110:1593-1600

Sardana MK, Kappas A (1987) Dual control mechanism for heme oxygenase: tin (IV)-protoporphyrin potently inhibits enzyme activity while markedly increasing content of enzyme protein in liver. Proc Natl Acad Sci USA 84:2464-2468

Siddiqui R, lqbal J, Maugueret MJ, Khan NA (2012) The role of Src kinase in the biology and pathogenesis of Acanthamoeba castellanii. Parasit Vectors 5:112

Sissons J, Kim KS, Stins M, Jayasekera S, Alsam S, Khan NA (2005) Acanthamoeba castellanii induces host cell death via a phosphatidylinositol 3-kinasedependent mechanism. Infect Immun 73:2704-2708

Thorson LM, Turkalj A, Hung JC (1995) In vitro evaluation of neutrophil viability after exposure to a hypotonic medium. Nucl Med Commun 16:615-620

doi:10.1186/2191-0855-2-47

Cite this article as: Siddiqui and Khan: Photochemotherapeutic strategies against Acanthamoeba keratitis. AMB Express 2012 2:47.

\section{Submit your manuscript to a SpringerOpen ${ }^{\circ}$ journal and benefit from:}

- Convenient online submission

- Rigorous peer review

- Immediate publication on acceptance

- Open access: articles freely available online

- High visibility within the field

- Retaining the copyright to your article

Submit your next manuscript at $>$ springeropen.com 